\title{
Connectivity to computers and the Internet among patients with schizophrenia spectrum disorders: a cross-sectional study
}

This article was published in the following Dove Press journal:

Neuropsychiatric Disease and Treatment

27 April 2017

Number of times this article has been viewed

\author{
Maritta Välimäki ${ }^{1-3}$ \\ Lauri Kuosmanen ${ }^{1,4,5}$ \\ Heli Hätönen' \\ Marita Koivunen ${ }^{1,6}$ \\ Anneli Pitkänen ${ }^{7}$ \\ Christina Athanasopoulou' \\ Minna Anttila' \\ 'Department of Nursing Science, \\ Faculty of Medicine, University of \\ Turku, Finland; ${ }^{2}$ Development Unit, \\ Turku University Hospital, Turku, \\ Finland; ${ }^{3}$ School of Nursing, Hong \\ Kong Polytechnic University, Kowloon, \\ Hong Kong, SAR, China; ${ }^{4}$ University \\ of Helsinki and Helsinki University \\ Hospital, Helsinki, Finland; ${ }^{5}$ Social \\ and Healthcare Department, City of \\ Vantaa, Vantaa, Finland; ' $\mathrm{Administrative}$ \\ Centre, Research and Development, \\ Satakunta Hospital District, Pori, \\ Finland; ${ }^{7}$ Administration Centre, \\ Pirkanmaa Hospital District, Tampere, \\ Finland
}

Correspondence: Maritta Välimäki Department of Nursing Science, 20014 University of Turku, Turku, Finland Tel +358406890546

Email mava@utu.fi
Purpose: Information and communication technologies have been developed for a variety of health care applications and user groups in the field of health care. This study examined the connectivity to computers and the Internet among patients with schizophrenia spectrum disorders (SSDs).

Patients and methods: A cross-sectional survey design was used to study 311 adults with SSDs from the inpatient units of two psychiatric hospitals in Finland. The data collection lasted for 20 months and was done through patients' medical records and a self-reported, structured questionnaire. Data analysis included descriptive statistics.

Results: In total, 297 patients were included in this study (response rate $=96 \%$ ). More than half of them $(n=156 ; 55 \%)$ had a computer and less than half of them $(n=127 ; 44 \%)$ had the Internet at home. Of those who generally had access to computers and the Internet, more than one-fourth ( $\mathrm{n}=85 ; 29 \%)$ used computers daily, and $>30 \%(\mathrm{n}=96 ; 33 \%)$ never accessed the Internet. In total, approximately one-fourth of them $(n=134 ; 25 \%)$ learned to use computers, and less than one-third of them $(n=143 ; 31 \%)$ were known to use the Internet by themselves. Older people (aged 45-65 years) and those with less years of education (primary school) tended not to use the computers and the Internet at all $(P<0.001)$, and younger people and those with higher education were associated with more active use.

Conclusion: Patients had quite good access to use computers and the Internet, and they mainly used the Internet to seek information. Social, occupational, and psychological functioning (which were evaluated with Global Assessment of Functioning) were not associated with access to and frequency of computer and the Internet use. The results support the use of computers and the Internet as part of clinical work in mental health care.

Keywords: digital divide, technology, mental illness, psychosis, survey

\section{Introduction}

Globally, the growth of the Internet use between 2000 and 2016 has been dramatic at $\sim 918 \%$, and it is constantly increasing. As of November 2016, Internet global penetration was 50\%, being the highest in North America, at 89\%, and the lowest in Africa, at $29 \%$. In Europe, the Internet penetration is the second highest globally at $74 \% .^{1}$ Internet use accompanied with a variety of information and communication technologies (ICTs) has the potential to improve information management, access to public services, and cost containment ${ }^{2,3}$ and also to improve services ${ }^{4}$ in mental health. In general, ICTs relate to technologies that facilitate the transfer of information and various types of electronically mediated communication. ${ }^{5}$ 
Consequently, the Internet use is also increasing fast among health care consumers. ${ }^{6}$ Health-related Internet use is not limited to public Web sites and information seeking, but also complements treatment through online self-help support programs and monitoring systems. ${ }^{7}$ Technology-assisted self-assessment methods have been developed to improve the quality and use of clinical information such as patients' symptoms. ${ }^{8}$ ICTs have also been used to offer patients and their families educational interventions, ${ }^{9}$ and they have been widely used on various cognitive rehabilitation programs. ${ }^{9}{ }^{10}$ Because of anonymity and easy access, the Internet became an important source of information for those with chronic or stigmatizing conditions ${ }^{11-13}$ such as schizophrenia spectrum disorders (SSDs).

Although the penetration of ICTs among the general public is high in Europe, some parts of the population are still not using the technologies. ${ }^{14}$ Many Europeans still derive too little benefit from ICTs, and millions are at a risk of being left behind; there remains a gap between ICT users and non-ICT users. Several reasons have been mentioned for this "digital divide," from missing infrastructure to missing ICT use to a lack of computer literacy or skills to enter into the information society. ${ }^{15}$ On the other hand, ICT engagement can also be seen as a dynamic continuum of use, rather than a simple divide between the users and non-users. Bradbrook and Fisher ${ }^{16}$ introduced the "5 Cs" framework to explain digital inclusion: connectivity (access), capability (skills and employability), content (quality- or communityfocused content), confidence (self-efficacy or motivation), and continuity (continuous and ongoing usage).

However, computer and the Internet skills are a new type of skills needed to perform the day-to-day activities. ${ }^{17}$ Clear differences in the levels of the Internet skills have been found with regard to sex, occupation, education, and location. Based on these factors, people with more advanced skills and being frequent Internet users can be characterized as men, service workers, highly educated, and living in metropolitan areas. ${ }^{18}$ Moreover, women who were under 65, completed college graduation, had more online experience, and had broadband access were most likely to seek online health information, ${ }^{19}$ and those using the Internet are a great deal better informed on health issues. ${ }^{20}$ Details on expertise, comfort using the Internet, and the location of access were less well reported. ${ }^{21}$

Trustworthy and illness-related information on severe mental health problems such as SSDs available on the Internet should still be developed, as it has been shown that schizophrenia-related online information tends to be of low quality. ${ }^{22}$ Schrank et $\mathrm{al}^{23}$ found that patients diagnosed with long-term schizophrenia use the Internet in a similar way as the general public uses. The authors also found that the Internet is a source of illness-related information for patients. The Internet-related problems included stimulus overflow, inability to deal with the abundance of information, difficulties with concentration, lack of energy, paranoid ideas, symptom provocation, and the need to distance themselves from the illness-related topics. ${ }^{23}$ The Internet can also be seen as a form of peer support for individuals with psychiatric disabilities, although a recent systematic review and meta-analysis found little evidence on the effects of peer support for people with severe mental illness. ${ }^{24,25}$ In addition, the evidence base of the effects of ICT-based prompting on treatment compliance for people with serious mental illness is still inconclusive, and further studies are warranted. ${ }^{26}$

Especially during the last decade, ICTs have been developed for a variety of health care applications, applicable to many diagnoses. ${ }^{27}$ However, ICT applications tended to focus on physical health, and little was known about ICT applications in the field of mental health. ${ }^{28}$ Recently, more studies have been conducted on ICT use and applications among people with mental illness, ${ }^{29-31}$ even though there is a gap in the literature on the use of ICT from this population before $2010 .^{28}$ Therefore, evidence on the potential growth of ICT use by this population is missing. Filling this gap might provide more insights into the progress and development of access and ICT use by individuals with SSDs. Thus, providing evidence on the potential growth of ICT use and access among people with SSDs could support the opportunities to minimize the risk of e-exclusion and compensate patients' poorer possibilities to consult with physicians or other health professionals because of low income. ${ }^{32,33}$

The present study aimed at examining, first, the prevalence and frequency of computer and the Internet use among patients with SSDs and, second, the patient characteristics associated with computer and the Internet use and the frequency of use. Being aware of the opportunities to use ICTs as a part of recovery, it might be possible to make plans for better integration of the patients with SSDs into the information society. As this study aimed at contributing to digital inclusion, the first component of Bradbrook and Fisher's framework, ${ }^{16}$ connectivity, is explored. In this study, connectivity refers to the connection between people with SSDs and computers and the Internet use (access, frequency of use, place of computer use, learning method, and purpose of using the computer). This study aimed at shedding light into ICT use among people with SSDs for a period when not so much of information on the topic was reported for this population, and it is important that as SSDs are chronic 
conditions with poor long-term outcomes, ${ }^{34}$ people with SSDs tend to be marginalized and to avoid treatment, which adds to the overall economic, personal, and societal burden of the illness. This study might assist future mental health interventions and efforts that seek to use computers and the Internet to reach and engage underserved populations, such as those with SSDs. In clinical mental health works, professionals and those working in close collaboration with patients have higher awareness about patients' ICT needs and what support and ICT-related training they need.

\section{Patients and methods Design}

The present study was designed based on a cross-sectional and registered survey (ISRCTN74919979). The data originally came from a large-scale national research project (Mieli.Net, Academy of Finland 207384) where a computerbased self-management system for patients with SSDs was developed and tested ${ }^{35-38}$ from a variety of perspectives.

This study was carried out in nine 24-h inpatient units in two psychiatric hospitals in southern Finland. Included were patients who 1) were aged 18-65 years; 2) were diagnosed with SSDs (F20-29; ICD-10); ${ }^{39} 3$ ) had the ability to speak and write Finnish; and 4) were willing to participate and provide written informed consent. Excluded were those who 1 ) were aged $<18$ years or $>65$ years; 2 ) were not having a primary diagnosis of SSDs (F20-29); 3) were unable to understand, speak, and/or read Finnish; and 4) were unwilling to participate.

\section{Instruments}

The data were collected, first, from the patients' records and, second, from a pen-and-pencil structured questionnaire, which was developed based on the related literature. First, demographic data including age and educational qualifications were collected from the patients' records by the nurses on the research wards. In addition, information on the social, occupational, and psychological functioning was evaluated using the Global Assessment of Functioning (GAF) at the time of admission, ${ }^{40}$ and the diagnostic data were provided by the physicians based on the patients' medical records.

Second, data concerning computer and the Internet use were collected by a self-rating structured questionnaire that was developed for this study and that consisted of 10 items (five for computer use and five for the Internet use): 1) the availability of computer at home (yes/no); 2) access to the Internet from home (yes/no); 3) the frequency of computer use (daily/ weekly/monthly/less than monthly/not at all); 4) the frequency of the Internet use (daily/weekly/monthly/less than monthly/ not at all); 5) the place of computer use (home/library/school/ workplace/Internet café/other); 6) the place of the Internet use (home/library/school/work/Internet café/other); 7) how the patients have learned to use the computers (self-taught/ friend-taught/ICT courses/professional education/working life/basic education/other); 8) how the patients have learned to use the Internet (self-taught/friend-taught/ICT courses/ professional education/working life/basic education/other); 9) the purpose of computer use (typing/gaming/economic calculations/presentations/graphic presentations/filing/other); and 10) the purpose of the Internet use (seeking information/studying/ online chatting/shopping/gaming/peer support/other).

\section{Data collection}

Research assistants distributed the questionnaire to the eligible patients during the patients' hospital stay from March 2005 to October 2006 (20 months). Of the 2,793 patients admitted to the inpatient units, 829 met the inclusion criteria, of which, $518(62 \%)$ refused to participate in this study. Of the patients excluded, 56\% were female, and the average age was 40.2 years (standard deviation $[\mathrm{SD}]=12.2) .{ }^{38}$ Finally, $311(38 \%)$ patients were eligible and willing to participate in the present study and received the questionnaire, and 297 of them returned it (response rate $=96 \%$ ). The high response rate was explained by the availability of a full-time research assistant present while the patients filled the questionnaire.

\section{Data analysis}

The data were first analyzed by using descriptive statistics (frequencies, means, and standard deviations) after recategorization of some variables as follows: age was categorized into three groups: 1) 18-24 years, 2) 25-44 years, and 3) 45-65 years. These categories were chosen because at the time of data collection the patients aged over 45 years have had only limited possibilities to computer and the Internet experiences, for example, during their basic education; the patients in the age-group of 25-44 have had some basic education related to computer and the Internet; and the patients in the age-group of 18-24 have had already quite good ICT education. GAF was recategorized into two groups: 1) scores $=1-48$ describing impaired functioning and 2) scores $\geq 49$ describing moderate or good functioning.

Then, the categorical data were analyzed by using nonparametric inferential statistics. The differences in the study variables were examined by using cross-tabulations and $\chi^{2}$ statistics. Assumptions such as categorical variables, sufficient expected counts in cells, and the minimum of 
$20 \%$ of the theoretical cell frequencies having less than five observations and independent samples/measurements were observed; $\chi^{2}$ statistics were also used to examine the associations between the background variables (age, basic education, professional education, and GAF) with the study variables. $P$-values reported in the present study were from whole cross table, and pairwise comparisons were not done, but the results were interpreted using frequencies and percentages between groups. The IBM Statistical Package for the Social Sciences Version 22.0 (IBM Corporation, Somers, NY, USA) for Windows was used to analyze the data.

\section{Ethical issues}

The present study was carried out according to the basic principles of research ethics. ${ }^{41,42}$ The study procedure was evaluated by the Local Ethics Committee of the Pirkanmaa Hospital District (ETLR01181), and permission to conduct the study was obtained from the directors of the organizations. The participants were provided with written and oral information about the study from the treating nurse and the research assistant. Assurances of anonymity, confidentiality, and patients' right to withdraw from the study at any time were given. The patients were ensured that participation or refusal would not affect their care. A code number for each completed questionnaire was assigned to ensure anonymity. Written informed consent was obtained from all of the study participants.

\section{Results}

\section{Characteristics of the participants}

Of the 297 participants, half of them $(n=146 ; 49 \%)$ were aged 25-44 years, more than one-third of them $(n=103 ; 34 \%)$ were aged 45-65 years, and less than one-fifth of them $(n=48$; $16 \%)$ were aged $18-24$ years. In total, $59 \%$ of them $(n=174)$ were male; $68 \%(n=190)$ of the respondents had primary school education as their basic education, one-third of the respondents had no vocational training $(n=96 ; 34 \%)$, less than one-fifth $(n=46 ; 16 \%)$ had taken short vocational courses, more than one-third $(n=109 ; 39 \%)$ had secondary level vocational education, and only every tenth $(n=29 ; 10 \%)$ had university education. GAF scores ( mean $=47.0$, median $=45$, $\mathrm{SD}=16.7, \min =12, \max =97$ ) indicated that the patients in our study had low or moderately low functioning.

\section{Computer and the Internet use among patients with SSDs}

Of the 286 respondents, more than half of them $(n=156 ; 55 \%)$ had computer, and less than half of them $(n=127 ; 44 \%)$ had the Internet access at home. More than one-fourth $(n=85$;
$29 \%$ ) used a computer daily, whereas almost one-fourth $(n=70 ; 24 \%)$ used the Internet. A bit less than one-fourth $(n=71 ; 24 \%)$ did not use a computer at all, and one-third of them $(n=96 ; 33 \%)$ did not use the Internet. The patients were able to choose several options for place to use computer and the Internet, learning method, and purposes for computer and the Internet use. Home was the most common place for computer $(\mathrm{f}=172 ; 26 \%)$ or the Internet use $(\mathrm{f}=142 ; 25 \%)$, and public library was the second most common place (computer use: $\mathrm{f}=130,19 \%$; Internet use: $\mathrm{f}=109,20 \%$ ). About onefourth taught themselves how to use the computer ( $\mathrm{f}=134$; $25 \%$ ), and less than one-third taught themselves how to use the Internet (self-taught; $f=143 ; 31 \%$ ), and less than onefifth of them learned with help from friends (friend-taught) (computer use: $f=92,17 \%$; Internet use: $f=86,18 \%$ ). The patients used computers mostly for typing $(\mathrm{f}=185 ; 24 \%)$ and gaming ( $\mathrm{f}=153 ; 20 \%$ ), whereas they used the Internet mostly for information seeking $(\mathrm{f}=198 ; 31 \%)$ and study purpose $(\mathrm{f}=105 ; 17 \%$; Table 1$)$.

Table I Computer and Internet use among patients with SSDs

\begin{tabular}{|c|c|c|}
\hline & $\begin{array}{l}\text { Computer } \\
\text { use }(n=286)\end{array}$ & $\begin{array}{l}\text { Internet } \\
\text { access }(n=291)\end{array}$ \\
\hline \multicolumn{3}{|l|}{ At home } \\
\hline Yes & $156(54.5)$ & $127(43.6)$ \\
\hline \multirow[t]{2}{*}{ No } & $130(45.5)$ & $164(56.4)$ \\
\hline & $\begin{array}{l}\text { Computer } \\
(n=295)\end{array}$ & $\begin{array}{l}\text { Internet } \\
(n=292)\end{array}$ \\
\hline \multicolumn{3}{|l|}{ Frequency of use } \\
\hline Daily & $85(28.8)$ & $70(24.0)$ \\
\hline Weekly & $68(23.1)$ & $65(22.3)$ \\
\hline Monthly & $26(8.8)$ & $27(9.2)$ \\
\hline Less than monthly & $45(15.3)$ & $34(11.6)$ \\
\hline \multirow[t]{2}{*}{ Not at all } & 7I (24.I) & $96(32.9)$ \\
\hline & $\begin{array}{l}\text { Computer } \\
(\mathrm{f}=672)\end{array}$ & $\begin{array}{l}\text { Internet } \\
(\mathrm{f}=558)\end{array}$ \\
\hline \multicolumn{3}{|l|}{ Place of use } \\
\hline Other & $83(12.4)$ & $67(12.0)$ \\
\hline Internet café & $45(6.7)$ & $48(8.6)$ \\
\hline Work & $115(17.1)$ & $86(15.4)$ \\
\hline School & $127(18.9)$ & $106(19.0)$ \\
\hline Library & $130(19.3)$ & $109(19.5)$ \\
\hline \multirow[t]{2}{*}{ Home } & $172(25.6)$ & $142(25.4)$ \\
\hline & $\begin{array}{l}\text { Computer } \\
(\mathrm{f}=533)\end{array}$ & $\begin{array}{l}\text { Internet } \\
(f=46 I)\end{array}$ \\
\hline
\end{tabular}

\begin{tabular}{lll}
\hline Learning method & & \\
Self-taught & $134(25.1)$ & $143(3 \mid .0)$ \\
Friend-taught & $92(17.3)$ & $86(18.7)$ \\
ICT courses & $81(15.2)$ & $46(10.0)$ \\
Professional education & $76(14.3)$ & $59(12.8)$ \\
Working life & $74(13.9)$ & $18(3.9)$ \\
Basic education & $54(10.1)$ & $38(8.2)$ \\
Other & $22(4.1)$ & 71 (I5.4) \\
\hline
\end{tabular}


Table I (Continued)

\begin{tabular}{lll}
\hline & $\begin{array}{l}\text { Computer } \\
(\mathbf{f}=\mathbf{7 6 0})\end{array}$ & - \\
\hline Purposes & $185(24.3)$ & - \\
Typing & $153(20.1)$ & - \\
Gaming & $98(12.9)$ & - \\
Economic calculations & $89(11.7)$ & - \\
Presentations & $83(10.9)$ & - \\
Graphic presentations & $78(10.3)$ & - \\
Filing & $74(9.7)$ & - \\
Other & - & Internet \\
\hline & & $(\mathbf{f = 6 3 3 )}$ \\
\hline
\end{tabular}

\begin{tabular}{lll}
\hline Purposes & & \\
Seeking information & - & $198(31.3)$ \\
Studying & - & $105(16.6)$ \\
Online chatting & - & $90(14.2)$ \\
Shopping & - & $80(12.6)$ \\
Gaming & - & $76(12.0)$ \\
Peer support & - & $32(5.1)$ \\
Other & - & $52(8.2)$ \\
\hline
\end{tabular}

Note: The values are provided as $n$; number of respondents (\%) and $f$; number of responses when patients were able to choose several options (\%).

Abbreviations: SSDs, schizophrenia spectrum disorders; ICT, information and communication technology.

\section{Association between patient characteristics and computer and the Internet use}

The patients aged 18-24 years had significantly more opportunities to use both computers $(\mathrm{n}=35,76 \%$, versus $\mathrm{n}=11,24 \%)$ and the Internet $(\mathrm{n}=30,65 \%$, versus $\mathrm{n}=16,35 \%)$ at home compared with patients in the older age-groups $(P<0.001)$. In addition, those with higher education (basic and/or vocational education) were significantly more prevalent in using computer and the Internet at home, and those with university education were significantly more prevalent in using a computer at home $(n=20 ; 69 \%)$ compared with those with a lower level of education $(\mathrm{n}=51,57 \% ; P=0.039)$. Age and level of education played a crucial role in computer and the Internet use as statistically significant differences were found. On the other hand, patients' functioning (evaluated with GAF) did not seem to affect computer $(P=0.260)$ or the Internet $(P=0.091)$ use (Table 2 ).

The patients in the age-group of 25-44 years used both computers $(n=52,35 \%$, versus $n=20,20 \%)$ and the Internet $(\mathrm{n}=43,30 \%$, versus $\mathrm{n}=15,15 \%)$ more often on a daily basis $(P<0.001)$ than the patients in the older-age category. The patients with lower basic education (primary school education) had never used computers (not at all; $n=60,33 \%$, versus $n=8$, $8 \%)$ or the Internet $(n=79,43 \%$, versus $n=13,14 \%)$, which was found to be statistically significant when compared with groups with higher education levels $(P<0.001$; Table 3$)$.

GAF scores showed no statistically significant associations with access to computer $(P=0.260)$ and the Internet $(P=0.091)$ use and the frequency of computer $(P=0.312)$ and the Internet $(P=0.136)$ use. The associations between GAF scores and 1) place for computer and the Internet use, 2) learning methods for computer and the Internet use, and 3) purpose for computer and the Internet use were also explored. Only one statistically significant association was found: the patients with low functioning scores were less likely to use computer at work ( $\mathrm{n}=112,47 \%$ versus $53 \% ; P=0.033$ ).

\section{Discussion}

The aim of this study was to examine, first, the prevalence and frequency of computer and the Internet use among

Table 2 Access to computers and the Internet from home

\begin{tabular}{|c|c|c|c|c|c|c|c|c|}
\hline & \multirow[t]{2}{*}{$\begin{array}{l}\text { Patients } \\
\text { (n) }\end{array}$} & \multicolumn{2}{|c|}{$\begin{array}{l}\text { Opportunity to use } \\
\text { computer at home, n (\%) }\end{array}$} & \multirow[t]{2}{*}{$P$-value } & \multirow[t]{2}{*}{$\begin{array}{l}\text { Patients } \\
\text { (n) }\end{array}$} & \multicolumn{2}{|c|}{$\begin{array}{l}\text { Opportunity to use } \\
\text { Internet at home, n (\%) }\end{array}$} & \multirow[t]{2}{*}{$P$-value } \\
\hline & & Yes & No & & & Yes & No & \\
\hline \multicolumn{4}{|l|}{ Age } & $<0.001$ & & & & $<0.001$ \\
\hline 18-24 years & 46 & $35(76.1)$ & II (23.9) & & 46 & $30(65.2)$ & $16(34.8)$ & \\
\hline $25-44$ years & 143 & $84(58.7)$ & $59(4 I .3)$ & & 145 & $64(44.1)$ & $8 \mathrm{I}(55.9)$ & \\
\hline $45-65$ years & 97 & $37(38.1)$ & $60(6 I .9)$ & & 100 & $33(33.0)$ & $67(67.0)$ & \\
\hline \multicolumn{4}{|l|}{ Basic education } & $<0.001$ & & & & $<0.001$ \\
\hline Primary school & 175 & $78(44.6)$ & $97(55.4)$ & & 182 & $59(32.4)$ & $123(67.6)$ & \\
\hline Secondary school graduate & 95 & $68(7 \mid .5)$ & $27(28.5)$ & & 93 & $60(64.5)$ & $33(35.5)$ & \\
\hline \multicolumn{4}{|l|}{ Professional education } & 0.039 & & & & 0.208 \\
\hline No vocational education & 90 & $5 \mathrm{I}(56.7)$ & $39(43.3)$ & & 91 & $4 I(45.1)$ & $50(54.9)$ & \\
\hline Short courses & 44 & $16(36.4)$ & $28(63.6)$ & & 45 & $13(28.9)$ & $32(7 I .1)$ & \\
\hline $\begin{array}{l}\text { Secondary level } \\
\text { vocational education }\end{array}$ & 106 & $57(53.8)$ & $49(46.2)$ & & 109 & $49(45.0)$ & $60(55.0)$ & \\
\hline University education & 29 & $20(69.0)$ & $9(3 \mid .0)$ & & 28 & I4 (50.0) & $14(50.0)$ & \\
\hline \multicolumn{4}{|l|}{ Global Assessment of Functioning* } & 0.260 & & & & 0.091 \\
\hline Scores $1-48$ & 153 & $79(51.6)$ & $74(48.4)$ & & 153 & $60(39.2)$ & $93(60.8)$ & \\
\hline Scores 49-100 & 125 & $73(58.4)$ & $52(4 \mid .6)$ & & 130 & $64(49.2)$ & $66(50.8)$ & \\
\hline
\end{tabular}

Note: $* I=$ minimum functioning, $100=$ maximum functioning. 


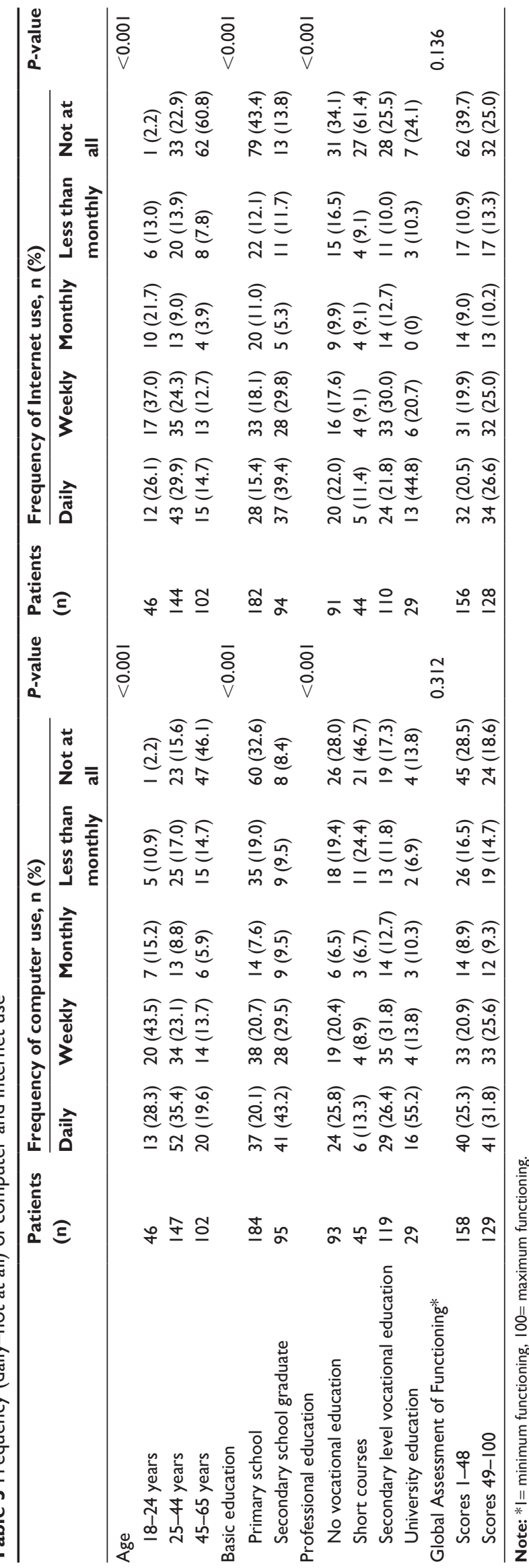

patients with SSDs and, second, the associations between patient characteristics and computer and the Internet use. The findings from this study showed that more than half of the participants had a computer, and less than half of them had the Internet access at home. The participants who were aged 18-24 years, secondary school graduates, and more specifically university graduates used computers and the Internet the most. Even though daily use of computer and the Internet was exhibited by those who were $25-44$ years old, secondary school graduates, university graduates, and with higher GAF scores, participants' level of functioning (GAF scores) did not appear to significantly affect the access to and frequency of computer and the Internet use.

In this study, the patients with SSDs exhibited $\sim 10 \%$ lower home Internet access than the general Finnish population in $2006,{ }^{43}$ which was, however, the same as the European average at that time. ${ }^{44}$ This percentage was lower than the Finnish general population, even though not very dissimilar, especially when current similar studies on Finnish adults with SSDs showed that the majority of them used computers and the Internet, ${ }^{45}$ as the general public. The slightly lower Internet use among those with SSDs can be because of the economic difficulties of this population, ${ }^{46}$ lack of basic ICT skills, or apprehension toward computers and the Internet. ${ }^{47}$ Therefore, novel interventions supporting and integrating patients with SSDs into the information society are required. ${ }^{37}$ Positive treatment results, ${ }^{48,49}$ an increase in patients' knowledge about illness, ${ }^{49}$ and diminished stigma associated, for example, with depression, after using the Internet programs ${ }^{50}$ should be highlighted in order to promote commitment to care.

On the other hand, although about half of the respondents had a computer and the Internet at home, they were not very active users. This can be attributed to schizophrenia's symptoms, like attention deficit or delusional interpretations, ${ }^{51}$ and motivational deficits, ${ }^{52}$ which lead to even greater exclusion. Computer and the Internet courses intended for people with cognitive difficulties could be offered for those who were going through an SSD rehabilitation process. This training could be conducted, for example, in volunteering mental health services in a peer-led support group. Naturally this should take these people's personal motivation into account, which affects their willingness to be ICT-trained and overall Internet use. ${ }^{52}$

As in the previous studies, ${ }^{53}$ in the present study also, patients with younger age and better education used computer and the Internet more actively. Thus, the findings from this present study showed that it is important to pay attention to middle-aged and aged SSD patients. This is especially 
important in Finland, where aging population is more common, than in other European countries. ${ }^{54}$ In addition, the development work should focus on those with lower basic and vocational education, since those are the people more likely to be excluded from the digital world.

Peer support is one important element in coping with longterm mental health problems. ${ }^{55,56}$ It seems that the patients in the present study were not sufficiently aware of this, and peer support was rarely mentioned as a purpose for using the Internet. The Internet use is one important method in social support. ${ }^{57}$ As unmoderated Internet-based peer support may increase the level of distress among people with psychiatric disabilities, it is important to develop and study structured and moderated methods for peer support in the Internet. ${ }^{58}$

Public services such as libraries and schools are important places, which ensure that everyone, including people with mental health problems, has Internet access. In order to achieve this close collaboration between mental health and other professionals, it is essential to ensure full participation of people with disabilities. ${ }^{59}$ Further, other professionals' knowledge level and positive attitudes related to mental health problems need to be ensured.

The role of ICT in mental health services and research continues to expand in the future as consumers, caregivers, health professionals, and the general population go online. ${ }^{60}$ However, the special needs of people with disabilities should be taken into account, and those in a need of advanced support (older people and those with lower education) should be systematically trained and familiarized with ICT. In addition, nurses working with these people in mental health care and in other services need to have sufficient ICT competence ${ }^{61,62}$ and have positive attitudes toward ICT.

The present study has certain limitations. First, the data collection was completed a decade ago (2006); thus, the results might seem outdated. However, in 2006, the literature was lacking of studies such as this for the specific population. The present study addressed a gap in the literature related to ICT use among patients with SSDs, and they were a group of patients whose needs must be brought to the fore in society. The ways in which the Internet is used have changed since the data collection period, and one of the most important reasons for this is smart phones. The present study described the situation before the era of smart phones and can, therefore, be used as a reference point for future studies as part of documenting trends in computer and the Internet use among patients with SSDs. Therefore, recommendations emanating from this study would be obsolete, from the point of view of the high-speed development of technology. Second, the instrument used was developed for this study based on previous literature, which was not an established one. Nonetheless, the number of questions was small, and the questions were kept simple considering the possible cognitive limitations of the participants because of their diagnosis. More specific information on the purpose of information use, as an example, was not asked even though it could have provided us valuable and detailed information. Third, data were self-reported; thus, selective and/or social desirability bias could affect responders' answers. However, the information letter and the oral instructions to the participants made clear to them that their answers would be treated confidentially and would not affect their treatment, and thus, they were reassured they could be as honest as possible.

\section{Conclusion}

This study illustrated that similar to the general population, the patients with SSDs with lower education level and older age have less opportunities to use computers and the Internet. As minimizing existing disparities in ICT access is the key to empower patients to use ICTs for supporting their healthrelated decisions, a clinical work needs to be adjusted to these groups' needs and individual preferences. It is obvious that demographic and individual factors influence ICT engagement. For example, mental health information and interventions targeting younger, educated populations with SSDs may use them online, whereas mental health information and interventions targeting older, lower education populations with SSDs could be successfully implemented offline. Anyhow, health professionals should ensure equal access to information across all ages and educational strata.

\section{Acknowledgments}

This research was funded by the Academy of Finland (213440 and 8214245). The authors wish to express their gratitude to Senior Lecturer, Jouko Katajisto, MSc, for statistical expertise.

\section{Disclosure}

The authors report no conflicts of interest in this work. The authors alone are responsible for the content and writing of the paper.

\section{References}

1. Internet World Stats. Usage and population statistics [updated December 16, 2016; cited June 30, 2016]. Available from: http://www. internetworldstats.com/stats.htm. Accessed February 14, 2017.

2. Thaker D, Monypenny R, Olver I, Sabesan S. Cost savings from a telemedicine model of care in northern Queensland, Australia. Med J Aust. 2013;199(6):414-417. 
3. Sands D, Wald J. Transforming health care delivery through consumer engagement, health data transparency, and patient-generated health information. Yearb Med Inform. 2014;9:170-176.

4. European Commission. Factsheet 35: i2010 - Strategy for an innovative and inclusive European Information Society 2008 [cited July 8, 2016]. Available from: http://ec.europa.eu/digital-agenda/en/news/factsheet35-i2010-strategy-innovative-and-inclusive-european-informationsociety. Accessed February 14, 2017.

5. Zuppo CM. Defining ICT in a boundaryless world: the development of a working hierarchy. IJMIT. 2012;4(3):13-22.

6. Lee CJ, Gray SW, Lewis N. Internet use leads cancer patients to be active health care consumers. Patient Educ Couns. 2010;81(Suppl):S63-S69.

7. Riper H, Andersson G, Christensen H, Cuijpers P, Lange A, Eysenbach G. Theme issue on e-mental health: a growing field in internet research. J Med Internet Res. 2010;12(5): 74.

8. Chinman M, Young AS, Schell T, Hassell J, Mintz J. Computer-assisted self-assessment in persons with severe mental illness. J Clin Psychiatry. 2004;65(10):1343-1351.

9. Barak A, Grohol JM. Current and future trends in internet-supported mental health interventions. J Tech Human Serv. 2011;29(3):155-196.

10. Eack SM, Hogarty GE, Greenwald DP, Hogarty SS, Keshavan MS. Cognitive enhancement therapy improves emotional intelligence in early course schizophrenia: preliminary effects. Schizophr Res. 2007;89(1-3): 308-311.

11. Powell J, Clarke A. Internet information-seeking in mental health: population survey. Br J Psychiatry. 2006;(189):273-277.

12. Bae JY. [Development of a user centered web site for mental health management in adolescents]. Taehan Kanho Hakhoe Chi. 2007;37(1): $14-25$. Korean.

13. Leach LS, Christensen H, Griffiths KM, Jorm AF, Mackinnon AJ. Websites as a mode of delivering mental health information: perceptions from the Australian public. Soc Psychiatry Psychiatr Epidemiol. 2007;42(2):167-172.

14. European Parliament. Bridging the digital divide in the EU. In: Negreiro M, editor. EPRS - European Parliamentary Research Service; 2015. Available from: http://www.europarl.europa.eu/RegData/etudes/ BRIE/2015/573884/EPRS_BRI(2015)573884_EN.pdf. Accessed February 14, 2017.

15. Demunter C. The Digital Divide in Europe. Statistics in Focus. 2005; 38. Available from http://www.attitudeweb.be/doc/resources/studies/ digital_divide_in_europe.pdf. Accessed March 20, 2017.

16. Bradbrook G, Fisher F. Digital equality reviewing digital inclusion activity and mapping the way forwards 2004 [cited April 2015]. Available from: http://www.citizensonline.org.uk/wp-content/uploads/939_ DigitalEquality1.pdf. Accessed February 14, 2017.

17. OECD. OECD Information Technology Outlook 2010 Highlights [cited June 3, 2016]. Available from: http://www.oecd.org/sti/ interneteconomy/46444955.pdf. Accessed February 14, 2017.

18. Ortega Egea JM, Recio Menéndez M, Román González MV. Diffusion and usage patterns of Internet services in the European Union. Information Res. 2007;12(2):302.

19. Fox S. Health information online. Washington, DC: Pew Internet and American Life Project; 2005 [cited June 3, 2016]. Available from: http:// www.pewinternet.org/Reports/2005/Health-Information-Online/1Summary-of-Findings.aspx. Accessed February 14, 2017.

20. Lee CJ. The role of Internet engagement in the health-knowledge gap. J Broadcast Electron Media. 2009;53(3):365-368.

21. Ybarra ML, Suman M. Help seeking behavior and the Internet: a national survey. Int J Med Inform. 2006;75(1):29-41.

22. Athanasopoulou C, Hätönen H, Suni S, Lionis C, Griffiths KM, Välimäki M. An analysis of online health information on schizophrenia or related conditions: a cross-sectional survey. BMC Med Inform \& Decis Mak. 2013;(13):98.

23. Schrank B, Sibitz I, Unger A, Amering M. How patients with schizophrenia use the internet: qualitative study. J Med Internet Res. 2010; 12(5):e70.
24. Lloyd-Evans B, Mayo-Wilson E, Harrison B, et al. A systematic review and meta-analysis of randomised controlled trials of peer support for people with severe mental illness. BMC Psychiatry. 2014;(14):39.

25. Välimäki M, Athanasopoulou C, Lahti M, Adams CE. Effectiveness of social media interventions for people with schizophrenia: a systematic review and meta-analysis. J Med Internet Res. 2016;18(4):e92.

26. Kauppi K, Välimäki M, Hätönen HM, Kuosmanen L, Warwick-Smith K, Adams CE. Information and communication technology based prompting for treatment compliance for people with serious mental illness. Cochrane Database Syst Rev. 2014;17(6):CD009960.

27. Black AD, Car J, Pagliari C, et al. The impact of eHealth on the quality and safety of health care: a systematic overview. PLoS Med. 2011; 8(1):e1000387.

28. Rotondi AJ, Eack SM, Hanusa BH, Spring MB, Haas GL. Critical design elements of e-health applications for users with severe mental illness: singular focus, simple architecture, prominent contents, explicit navigation, and inclusive hyperlinks. Schizophr Bull. 2015;41(2): $440-448$.

29. Ferron JC, Brunette MF, McHugo GJ, Devitt TS, Martin WM, Drake RE. Developing a quit smoking website that is usable by people with severe mental illnesses. Psychiatr Rehabil J. 2011;35(2):111-116.

30. Granholm E, Ben-Zeev D, Link PC, Bradshaw KR, Holden JL. Mobile Assessment and Treatment for Schizophrenia (MATS): a pilot trial of an interactive text-messaging intervention for medication adherence, socialization, and auditory hallucinations. Schizophr Bull. 2012;38(3): 414-425.

31. Rotondi AJ, Anderson CM, Haas GL, et al. Web-based psychoeducational intervention for persons with schizophrenia and their supporters: one-year outcomes. Psychiatr Serv. 2010;61(11):1099-1105.

32. Wofford JL, Smith ED, Miller DP. The multimedia computer for officebased patient education: a systematic review. Patient Educ Couns. 2005; 59(2):148-57.

33. Umefjord G, Petersson G, Hamberg K. Reasons for consulting a doctor on the Internet: web survey of users of an Ask the Doctor service. J Med Internet Res. 2003;5(4):e26.

34. Robinson D, Woerner MG, Alvir JM, et al. Predictors of relapse following response from a first episode of schizophrenia or schizoaffective disorder. Arch Gen Psychiatry. 1999;56(3):241-247.

35. Koivunen M, Välimäki M, Pitkänen A, Kuosmanen L. A preliminary usability evaluation of web-based portal application for patients with schizophrenia. J Psychiatr Ment Health Nurs. 2007;14(5):462-469.

36. Välimäki $\mathrm{M}$, Anttila $\mathrm{M}$, Hätönen $\mathrm{H}$, et al. Design and development process of patient-centred computer-based support system for patients with schizophrenia spectrum psychosis. Inform Health Soc Care. 2008; 33(2):113-123.

37. Kuosmanen L, Välimäki M, Joffe G, et al. The effectiveness of technology-based patient education on self-reported deprivation of liberty among people with severe mental illness: a randomized controlled trial. Nord J Psychiatry. 2009;63(5):383-389.

38. Pitkänen A, Välimäki M, Kuosmanen L, et al. Patient education methods to support quality of life and functional ability among patients with schizophrenia: a randomized clinical trial. Qual Life Res. 2012;21(2): 247-256.

39. World Health Organization. International Statistical Classification of Diseases and Related Health Problems 10th Revision; 2010. Available from: http://apps.who.int/classifications/icd10/browse/2010/en. Accessed February 14, 2017.

40. Williams JBW. Mental health status, functioning, and disabilities measures. In AJ Rush, MB First, D Blacker, editors. Handbook of Psychiatric Measures. Washington, DC: American Psychiatric Publishing; 2008:83-105.

41. European Commission. The EU Framework Programme for Research and Innovation. Horizon 2020 [cited June 3, 2016]. Available from: http://ec.europa.eu/research/participants/portal/doc/call/h2020/h2020msca-itn-2015/1620147-h2020_-_guidance_ethics_self_assess_en.pdf. Accessed February 14, 2017. 
42. World Medical Association. World Medical Association Declaration of Helsinki. Ethical Principles for Medical Research Involving Human Subjects; 2013 [cited June 3, 2016]. Available from: http:// jama.jamanetwork.com/article.aspx?articleid=1760318. Accessed February 14, 2017.

43. Eurostat. Place of Internet use by individuals; 2006. Available from: http:// ec.europa.eu/eurostat/statistics-explained/index.php?title=File:Place_ of_Internet_use_by_individuals,_2006.PNG\&oldid=527\#filehistory. Accessed February14, 2017.

44. Eurostat. Digital economy and society statistics - households and individuals. [updated November 29, 2016; cited November 8, 2016] Available from: http://ec.europa.eu/eurostat/statistics-explained/index. php/Digital_economy_and_society_statistics_-_households_and_ individuals\#Internet_access. Accessed February 14, 2017.

45. Athanasopoulou C. eHealth and people with Schizophrenia Spectrum Disorders [dissertation]. Annales Universitatis Turkuensis D 1275 : University of Turku; 2017.

46. Murali V, Oyebode F. Poverty, social inequality and mental health. Adv Psychiatr Treat. 2004;(10):216-224.

47. Moura de Holanda G, Castilho Dall'Antonia J. An approach for e-inclusion: bringing illiterates and disabled people into play. J Technol Manage Innov. 2006;1(3):29-37.

48. Emmenkamp PM. Technological innovations in clinical assessment and psychotherapy. Psychother Psychosom. 2005;74(6):336-343

49. Alemi F, Haack MR, Nemes S, Aughburns R, Sinkule J, Neuhauser D Therapeutic emails. Subst Abuse Treat Prev Policy. 2007;(2):7.

50. Griffiths KM, Christensen H. Internet-based mental health programs: a powerful tool in the rural medical kit. Austr J Rural Health. 2007; 15(2):81-87.

51. Kalk NJ, Pothier DD. Patient information on schizophrenia on the internet. Psychiatr Bull. 2008;(32):409-411.

52. Fervaha G, Graff-Guerrero A, Zakzanis KK, Foussias G, Agid O, Remington $\mathrm{G}$. Incentive motivation deficits in schizophrenia reflect effort computation impairments during cost-benefit decision-making. J Psychiatr Res. 2013;47(11):1590-1596.
53. Kontos E, Blake KD, Chou WYS, Prestin A. Predictors of eHealth usage: insights on the digital divide from the Health Information National Trends Survey 2012. JMIR. 2014;16(7):e172.

54. Parkkinen P. Suomen ja muiden unionimaiden väestörakenne 2050. [Population structure in Finland and in other union countries in 2050]. Government Institute for Economic Research, Finland. VATTkeskustelualoitteita 265, 2002.

55. Davidson L, Chinman M, Sells D, Rowe M. Peer support among adults with serious mental illness: a report from the field. Schizophr Bull. 2006; 32(3):443-450.

56. Salzer M. Consumer-delivered services as a best practice in mental health care and the development of practice guidelines. Psych Rehab Skills. 2002;6(3):355-382.

57. Murray E, Burns J, See TS, et al. Interactive health communication applications for people with chronic disease. Cochrane Database Syst Rev. 2005;4:CD004274.

58. Kaplan K, Salzer S, Solomon P, Brusilovskiy E, Cousonis P. Internet peer support for individuals with psychiatric disabilities: a randomized controlled trial. Soc Sci Med. 2011;72(1):54-62.

59. Commission of the European Communities. 'eAccessibility' - improving the access of people with disabilities to the knowledge based society. Official Journal of the European Union C 39/5; 2003 [cited June 18, 2016]. Available from: https://www.eumonitor.nl/9353000/1 j9vvik7m1c3gyxp/vi7jgstnckuq. Accessed February 14, 2017.

60. Cleary M, Walter G, Matheson S. What is the role of e-technology in mental health services and psychiatric research? JPsychosoc Nurs Ment Health Serv. 2008;46(4):42-48.

61. Repique RJ. Computers and Information Technologies in Psychiatric Nursing. Perspect Psychiatr Care. 2007;43(2):77-83.

62. Anttila M, Koivunen M, Välimäki M. Information technology-based standardized patient education in psychiatric inpatient care. $J A d v$ Nurs. 2008;64(2):147-156.
Neuropsychiatric Disease and Treatment

\section{Publish your work in this journal}

Neuropsychiatric Disease and Treatment is an international, peerreviewed journal of clinical therapeutics and pharmacology focusing on concise rapid reporting of clinical or pre-clinical studies on a range of neuropsychiatric and neurological disorders. This journal is indexed on PubMed Central, the 'PsycINFO' database and CAS,

\section{Dovepress}

and is the official journal of The International Neuropsychiatric Association (INA). The manuscript management system is completely online and includes a very quick and fair peer-review system, which is all easy to use. Visit http://www.dovepress.com/testimonials.php to read real quotes from published authors. 